\title{
Source versus Residence Based Taxation with International Mergers and Acquisitions
}

\author{
Johannes Becker \\ Clemens Fuest
}

CESIFO WORKING PAPER NO. 2854

CATEgORY 1: PUBlic FinANCE

NOVEMBER 2009

\footnotetext{
An electronic version of the paper may be downloaded

- from the SSRN website:

- from the RePEc website:

- from the CESifo website: 


\title{
Source versus Residence Based Taxation with International Mergers and Acquisitions
}

\begin{abstract}
This paper analyses tax competition and tax coordination in a model where capital flows occur in the form of mergers and acquisitions, rather than greenfield investment. In this framework, we show that differences in residence based taxes do not necessarily distort international ownership patterns. Moreover, tax competition yields globally efficient levels of source based corporate income taxes if residence based taxes on capital income are absent. In contrast, in the presence of residence based taxes on dividends, source based corporate income taxes are inefficiently high. The widespread view that tax coordination is less urgent if residence based taxes are available may therefore be misguided.
\end{abstract}

JEL Code: H54, H25, F23.

Keywords: corporate taxation, tax competition, mergers and acquisitions.

Johannes Becker

Max Planck Institute for Intellectual

Property

Competition and Tax Law

Department of Public Economics

Marstallplatz 1

Germany-80539 Munich

johannes.becker@ip.mpg.de
Clemens Fuest

Centre for Business Taxation

Said Business School

University of Oxford

Park End Street

Oxford OX1 HP

United Kingdom

clemens.fuest@sbs.ox.ac.uk

This version: $9^{\text {th }}$ November 2009

We thank participants at workshops and conferences in Munich and Magdeburg for helpful comments. We gratefully acknowledge financial support from the ESRC (Grant No RES 060-25-0033). 


\section{Introduction}

One of the most powerful theorems in the literature on international taxation and capital allocation is that residence based taxation is superior to source based taxation. As a consequence, models analysing optimal tax policy strategies under source based tax competition usually assume that residence based taxes are not available. However, most of these models are based on the implicit assumption that investment takes the form of greenfield investment. This neglects that a large part of international capital flows takes the form of mergers and acquisitions (M\&A). Since recent contributions claim that taking into account M\&A investment does lead to substantial changes in the efficiency properties of taxation, see e.g. Desai \& Hines (2004) and Becker \& Fuest (2008, forthcoming), it is important to investigate the role of residence based taxation in a model where investment takes the form of M\&A.

The purpose of this paper is to develop a simple model which may serve as an equivalent to the standard framework for tax competition based on greenfield investment, i.e. the reallocation of real capital instead of ownership. We consider a world with two countries, where domestic investors may either acquire existing firms at home and abroad or buy bonds in the international credit market. M\&A investment is driven by synergies. In this framework, we explore the impact of source and residence based capital income taxes.

A first important finding of our analysis is that international differences in residence based taxation do not necessarily distort ownership patterns. Secondly, we show that, if investment takes the form of M\&A instead of greenfield, the role of source and residence based taxes for international tax competition and coordination is different. In the baseline version of our model, the equilibrium corporate tax levels emerging under tax competition are globally optimal if residence based taxes on dividends are zero. There is no role for welfare enhancing tax coordination. In contrast, if residence based dividend taxes exist, tax competition yields inefficiently high level of corporate tax rates. The reason is that corporate taxation affects neighbouring countries negatively through two different channels. Corporate taxation of the host country reduces the tax base for residence based dividend taxation, and corporate taxation of the residence country reduces the price the 
acquirer is willing to pay for the target firm and, thus, decreases national income of the host country. Residence based taxes on interest income and dividends have complex external effects on the neighbouring countries' welfare levels as well. These effects are often ambiguous in sign and differ substantially between the residence and the host country. To deal with complexities arising due to the asymmetry of tax competition equilibria in our model, we consider a specific type of coordination experiment, which holds the relative tax burden on capital income in the two countries constant. We show that, firstly, a coordinated increase in residence based taxes on interest income only redistributes income across jurisdictions; welfare effects only emerge if the preferences for public goods differ. Secondly, dividend taxes can be shown to be inefficiently low if asymmetries between countries are small. Our results stand in sharp contrast to the existing tax competition literature where tax competition with source based taxes usually leads to inefficient equilibria, and international tax coordination is required to implement the globally optimal tax policy. In these models, the need for tax coordination is weakened and may even vanish if residence based taxes are available.

For purpose of presentational clarity and comparison with the standard case of greenfield investment, we focus on the polar case where investment consists exclusively of mergers and acquisitions. This implies the assumption that the stock of real capital (the existing target firms in our model) is constant and given. As we show in Becker \& Fuest (2008), considering greenfield investment and M\&A simultaneously adds some complexity and requires a number of assumptions which themselves limit the analytic scope with regard to tax effects on M\&A. This is why we choose to analyse the pure case of M\&A only in this paper. The assumption that there is no greenfield investment drives the efficiency result for the tax competition equilibrium with source based taxes only. Given this, in terms of policy conclusions, it would be inappropriate to question the potential for welfare enhancing coordination of source based taxes. But our findings do challenge the view that implementing residence based taxation may be a substitute for coordination.

In the literature, the issues of capital mobility and tax competition have been studied intensively, see Fuest, Huber \& Mintz (2005) for a recent survey. A broad and still growing empirical literature on the impact of taxes on investment and capital flows is surveyed by Devereux (2007). However, as noted above, these 
contributions usually assume that investment takes the form of greenfield investment. The literature dealing with the impact of taxes on M\&A is much smaller. In an early contribution, Devereux (1990) points out that tax distortions to ownership may be important if capital productivity depends on ownership. Gordon \& Bovenberg (1996) as well as Fuest \& Huber (2004) analyse tax policy strategies in models where firms may be sold to foreign investors. But they do not consider tax competition or tax coordination. Desai \& Hines (2004) argue that U.S. taxation of foreign source income is likely to distort ownership patterns and to put U.S. firms at a disadvantage when competing for foreign acquisitions. They propose to exempt foreign source income from domestic taxation. In Becker \& Fuest (forthcoming), we analyse this argument and show that exemption is an appropriate policy choice when ownership advantage is a public good within the firm, but is dominated in welfare terms by a cross-border cash-flow tax system. In Becker and Fuest (2008), we analyse tax competition in a model where M\&A and greenfield investment are alternative modes of entry and show that the existence of M\&A investment intensifies tax competition. However, this analysis does not include residence based taxes. Haufler \& Schulte (2007) consider tax incentives in a model where M\&A can take place within and across borders. They show that ownership patterns are highly important for the welfare implications of tax policy choices. From an empirical point of view, a number of contributions use the U.S. tax reform in 1986 to explore the tax effects on M\&A activity, see e.g. Auerbach \& Slemrod (1997). ${ }^{1}$ Swenson (1994) explores the idea that effective tax increases in the U.S. may induce investors located in countries with foreign tax credit regimes to take over U.S. firms because the higher U.S. taxes may be credited against home country taxes, and finds robust evidence supporting the hypothesis. In a recent paper, Huizinga \& Voget (forthcoming) study the empirical impact of international taxation schemes on M\&A activity. Among other things, they find that investors from tax credit countries are less likely to take over foreign firms than investors from countries where foreign profits are exempt from domestic taxation.

The remainder of the paper is set up as follows. In section 2, we present the model and derive the main results. In section 3, we consider some extensions.

\footnotetext{
${ }^{1}$ See also Scholes \& Wolfson (1990) and Collins, Kemsley \& Shackelford (1995). Empirical evidence on non-tax aspects of m\&a activity is reported in Andrade, Mitchell \& Stafford (2001).
} 
Section 4 discusses how the results relate to the literature and section 5 concludes.

\section{The model}

We consider a world consisting of two countries, domestic and foreign. Each country is inhabited by a large number of households. For notational convenience, their number per country is normalized to unity. Households live for two periods. The utility of the representative domestic household is given by $W=U\left(C_{1}, C_{2}\right)+H(G)$ where $C_{1}$ and $C_{2}$ are consumption in the first and the second period, $U\left(C_{1}, C_{2}\right)$ is private utility and $H(G)$ is utility from the provision of a public consumption good $G$ in period 2. For private utility, we assume $U\left(C_{1}, C_{2}\right)=u\left(C_{1}\right)+C_{2}$, where the subutility function $u($.$) is strictly concave, with u^{\prime}>0, u^{\prime \prime}<0$. This utility function implies that income effects on first period consumption are zero, so that the interest elasticity of savings is strictly positive. ${ }^{2}$ Accordingly, the utility function of the foreign representative household is denoted by $W^{*}=u^{*}\left(C_{1}^{*}\right)+C_{2}^{*}+H^{*}\left(G^{*}\right)$. The asterisk denotes the foreign country. In period 1 , the domestic and the foreign household have a given endowment of $E$ and $E^{*}$ units of a numeraire good, respectively. Households may borrow or lend in the international capital market at the interest rate $r .^{3}$

In addition, the domestic household owns $m$ existing and immobile firms operating in the domestic country. Without a change in ownership, the after tax profit earned by each domestic firm in period 2 is given by $\varepsilon(1-\tau)$, where $\tau$ is the domestic corporate income tax. Accordingly, the foreign household owns $m^{*}$ firms operating in the foreign country with an after-tax profit of $\varepsilon^{*}\left(1-\tau^{*}\right)$, where $\tau^{*}$ is the foreign corporate income tax.

The domestic household considers acquisitions of firms in the domestic and in the foreign country. To keep the model as simple as possible, we assume that the representative household in the foreign household does not consider acquisitions.

\footnotetext{
${ }^{2}$ This assumption is not critical but simplifies the exposition.

${ }^{3}$ The seminal contributions by Richman (1963) and Feldstein \& Hartman (1979) assume that domestic households only invest in the multinational firm's equity. A portfolio capital market is absent in these models. It is straightforward to show, however, that our results also hold if there is no portfolio capital market in our model. A formal derivation is available from the authors upon request.
} 
This asymmetry simplifies the exposition but also implies some complexities which are discussed in sections 3.3 to 3.5 .

If an existing domestic target firm is acquired by the domestic household, the change of ownership does not imply a relocation of real capital. But the ownership change does have a real economic effect in the form of synergies. This synergy increases the second period cash flow of the domestic target firm by $\Delta$. Equivalently, if a foreign target firm is acquired, second period cash flow increases by $\Delta^{*}$. We assume that each target firm is characterized by a specific synergy. More precisely, we assume that each potential target firm draws a synergy $\Delta$ or $\Delta^{*}$ from a uniform distribution with support $\left[\Delta^{-}, \Delta^{+}\right]$and $\left[\Delta^{*-}, \Delta^{*+}\right]$, respectively. The distribution functions are denoted by $\Omega(\Delta)$ and $\Omega^{*}\left(\Delta^{*}\right)$ and density functions are constant and normalized to unity to ease notation. This synergy is the driving force for changes in ownership in our model. The intuition behind this assumption is that the target firm has some specific asset (like customer relations, patents, brand names) which becomes more valuable in the hands of the acquirer. The value of these specific assets differs across target firms. Alternatively, one may think of adjustment costs which arise after the acquisition of a target firm. The lower the adjustment cost, the higher the net synergy $\Delta$ or $\Delta^{*}$.

An important question which arises in this context is whether the overall number of acquisitions is limited by e.g. managerial capacity. In the baseline version of our model, we assume that there is no limitation on the overall number of takeovers which may take place. In section 3.6, we will consider the case where the number of feasible acquisitions is limited due to constrained management capacities or convex transaction costs.

\subsection{The market for M\&A investment}

The market for acquisitions works as follows. In period 1, all domestic and foreign target firms draw a synergy $\Delta$ or $\Delta^{*}$. Then, the domestic household bids for target firms. At this stage, the target firm specific synergy is common knowledge. If the acquisition takes place, the acquirer has to pay the acquisition price $P$ to the vendor. In period 2 , the acquirer receives the cash flow generated by the target firm. 
For the tax treatment of acquisitions, we make the following assumptions. The revenue from selling firms is untaxed and investors cannot deduct acquisition costs from the corporate tax base. This may be interpreted as a highly stylised way of modelling acquisitions in the form of share deals, as opposed to asset deals. We thus abstract from many complexities associated with the tax consequences of mergers and acquisitions. These include e.g. capital gains taxes, the tax depreciation of goodwill, the transfer of reserves, the use of loss carryforwards after ownership changes and other specific tax law provisions of the national tax systems, some of which are surveyed in Huizinga \& Voget (forthcoming). We also abstract from tax planning considerations like e.g. the financing of foreign acquisitions with debt issued in high tax jursidictions to benefit from interest deductions. ${ }^{4}$

The domestic household's willingness to pay for a domestic target firm $j$ can be determined as follows. If she acquires the firm, she pays the acquisition price $P\left(\Delta_{j}\right)$ in period 1 . The payment of the acquisition price is financed by a reduction of the household's portfolio investment. The return on portfolio investment is $(1+r)(1-t)$, where $t$ is a residence based tax on income from portfolio investment. In period 2 , she receives the after tax cash flow $(\varepsilon+\Delta)(1-\tau)(1-\theta)$, where $\theta$ is a residence based tax on dividends. Given this, the highest aquisition price acquirers are willing to pay is given by

$$
(1+r)(1-t) P\left(\Delta_{j}\right)=\left(\varepsilon+\Delta_{j}\right)(1-\tau)(1-\theta)
$$

Competition among acquirers will imply that the equilibrium price of acquisitions will be given by $P\left(\Delta_{j}\right)$ as defined by (1). Given this, under which circumstances will domestic vendors sell their firms? If they sell, they may invest the proceeds in the market for portfolio capital or use them for consumption in period 1. Thus a domestic vendor will sell if the purchase price is equal to or larger than the present value of the second period income in case the firm is not sold:

$$
(1+r)(1-t) P\left(\Delta_{j}\right) \geq \varepsilon(1-\tau)(1-\theta)
$$

Since $P\left(\Delta_{j}\right)$, as defined in $(1)$, is increasing in $\Delta_{j}$, we may conclude that all

\footnotetext{
${ }^{4}$ For a survey of evidence on international tax planning see Devereux (2007).
} 
domestic target firms with $\Delta \geq \Delta^{c}$ will be acquired while firms which offer lower synergies will remain in the hands of their original owners. It follows from (1) and (2) that the cut-off level $\Delta^{c}$ is simply given by $\Delta^{c}=0$. This reflects that the domestic tax system is neutral for domestic acquisitions in this model.

In the case of foreign target firms, the acquisition price is given by

$$
(1+r)(1-t) P^{*}\left(\Delta_{j}^{*}\right)=\left(\varepsilon^{*}+\Delta_{j}^{*}\right)\left(1-\tau^{*}\right)(1-\theta)
$$

and the vendor is willing to sell if

$$
(1+r)\left(1-t^{*}\right) P^{*}\left(\Delta_{j}^{*}\right) \geq \varepsilon^{*}\left(1-\tau^{*}\right)\left(1-\theta^{*}\right)
$$

This yields the cutoff value

$$
\Delta^{c *}=\varepsilon^{*}\left[\left(\frac{1-\theta^{*}}{1-\theta}\right)\left(\frac{1-t}{1-t^{*}}\right)-1\right]
$$

which implies $\Delta^{c *}=\Delta^{c *}\left(t^{*}, t, \theta, \theta^{*}\right)$, with $\frac{\partial \Delta^{* c}}{\partial t^{*}}>0, \frac{\partial \Delta^{* c}}{\partial \theta^{*}}<0, \frac{\partial \Delta^{* c}}{\partial t}<0$ and $\frac{\partial \Delta^{* c}}{\partial \theta}>0$. Note that the source based corporate income tax $\tau^{*}$ does not affect the number of acquisitions. The reason is that this tax is capitalized in the purchase price - it always has to be paid, independent of who owns the firm. For residence based taxes, things are different. An increase in $t^{*}$ reduces the number of border crossing acquisitions because a lower return on portfolio investment increases the value of target firms in the hands of the initial foreign owners. The reason is that these firms offer a return in period 2 which is not subject to the tax on portfolio income. Put differently, an increase in this tax reduces the discount rate of foreign owners. For the same reason, an increase in $t$ increases border crossing acquisitions. A higher residence based tax on dividend income in the foreign country $\theta^{*}$ leads to more acquisitions because the acquirers are not subject to this tax. Accordingly, a higher domestic dividend tax $\theta$ reduces border crossing acquisitions.

Equation (5) allows to define conditions for ownership neutrality of the international tax system. In the absence of taxes, (5) boils down to $\Delta^{c *}=0$. Ownership neutrality would require that this equation holds in the presence of taxes, too. Source based taxes do not disturb ownership neutrality, as has been pointed out 
in the literature (Devereux, 1990). But interestingly, residence based taxes do not necessarily distort ownership neutrality either. For instance, if each country taxes dividends and interest income at the same rate, ownership neutrality prevails even if the tax rates differ across countries. The view that taxes on foreign source dividends may violate ownership neutrality is based on the idea that an investor from a country with high taxes will end up with a lower return on the acquisition of a given firm than an investor from a low tax country. But this neglects that the price an investor is willing to pay will also depend on the tax burden on alternative investments. If the tax on intererest income is also higher, this may neutralise the higher dividend tax, and no ownership distortions arise. We may state these results as

Proposition 1 Ownership neutrality:

i) International differences in source based taxation do not distort ownership allocation.

ii) Ownership neutrality is compatible with international differences in residence based capital income tax rates if $\frac{1-\theta^{*}}{1-\theta}=\frac{1-t^{*}}{1-t}$.

Proof. The proof directly follows from equation (5).

\subsection{The international credit market}

How do changes in taxes and investment affect the international credit market? Consider first the budget constraint of the domestic household. In the first period, the household's endowment $E$ may be used for consumption, credit market investment $S$ or for the financing of acquisitions. Expenditures for financing domestic acquistions are $\int_{\Delta^{c}}^{\Delta^{+}} P(\Delta) d \Delta$, but these expenditures flow back to the domestic household in the same period because the domestic household owns these firms in the first place. However, expenditures on acquisitions of foreign target firms, given by

$$
\int_{\Delta^{* c}}^{\Delta^{*+}} P^{*}\left(\Delta^{*}\right) d \Delta^{*}=\int_{\Delta^{* c}}^{\Delta^{*+}} \frac{\left(\varepsilon^{*}+\Delta_{j}^{*}\right)\left(1-\tau^{*}\right)(1-\theta)}{(1+r)(1-t)} d \Delta^{*}
$$

do not flow back to the domestic households and therefore have to be financed 
in addition. The budget constraint in period 1 is thus given by

$$
C_{1}=E-S-\int_{\Delta^{* c}}^{\Delta^{*+}} P^{*}\left(\Delta^{*}\right) d \Delta^{*}
$$

In the second period, the household receives income from investment in the international credit market and profit distributions from domestic and international M\&A investment. The budget constraint in the second period can be written as

$$
\begin{aligned}
C_{2}= & S(1+r)(1-t)+\left(m-\int_{\Delta^{c}}^{\Delta^{+}} d \Delta\right) \varepsilon(1-\tau)(1-\theta) \\
& +\int_{\Delta^{c}}^{\Delta^{+}}(\varepsilon+\Delta)(1-\tau)(1-\theta) d \Delta+\int_{\Delta^{* c}}^{\Delta^{*+}}\left(\varepsilon^{*}+\Delta^{*}\right)\left(1-\tau^{*}\right)(1-\theta) d \Delta^{*}
\end{aligned}
$$

Optimal choice of $S$ implies $u^{\prime}\left(C_{1}\right)=(1+r)(1-t)$. The foreign household has the following budget constraints

$$
\begin{aligned}
& C_{1}^{*}=E^{*}-S^{*}+\int_{\Delta^{* c}}^{\Delta^{*+}} P^{*}\left(\Delta^{*}\right) d \Delta^{*} \\
& C_{2}^{*}=S^{*}(1+r)\left(1-t^{*}\right)+\left(m^{*}-\int_{\Delta^{* c}}^{\Delta^{*+}} d \Delta^{*}\right) \varepsilon^{*}\left(1-\tau^{*}\right)\left(1-\theta^{*}\right)
\end{aligned}
$$

Optimal saving by the foreign household implies $u^{* \prime}\left(C_{1}^{*}\right)=(1+r)\left(1-t^{*}\right)$.

Equilibrium in the portfolio capital market requires that net lending equals net borrowing which implies that net savings have to equal zero, $S+S^{*}=0$. The two first order conditions for optimal savings and the credit market equilibrium condition determine the equilibrium values of $S, S^{*}$ and $r$, for given taxes and a given pattern of domestic and foreign acquisitions. How do taxes affect the capital market equilibrium? Consider first the effect of tax changes on the interest rate $r$.

Lemma The equilibrium interest rate $r$ is increasing in $t$ and $t^{*}$. Changes in the number or the prices of foreign acquisitions do not affect the interest rate $r$.

Proof. Totally differentiating $u^{\prime}=(1+r)(1-t)$ and $u^{* \prime}=(1+r)\left(1-t^{*}\right)$ yields

$$
d S=-d\left[\int_{\Delta^{* c}}^{\Delta^{*+}} P^{*}\left(\Delta^{*}\right) d \Delta^{*}\right]-\frac{1}{u^{\prime \prime}}[d r(1-t)-d t(1+r)]
$$


and

$$
d S^{*}=d\left[\int_{\Delta^{* c}}^{\Delta^{*+}} P^{*}\left(\Delta^{*}\right) d \Delta^{*}\right]-\frac{1}{u^{* \prime \prime}}\left[d r\left(1-t^{*}\right)-d t^{*}(1+r)\right]
$$

Using $d S+d S^{*}=0$ and adding up yields

$$
d r=\frac{1}{\gamma}\left[\frac{1+r}{u^{\prime \prime}} d t+\frac{1+r}{u^{* \prime \prime}} d t^{*}\right]
$$

with $\gamma=\frac{(1-t)}{u^{\prime \prime}}+\frac{\left(1-t^{*}\right)}{u^{* \prime \prime}}<0$. This implies $\frac{d r}{d t}>0, \frac{d r}{d t^{*}}>0, d r / d\left[\int_{\Delta^{* c}}^{\Delta^{*+}} P^{*}\left(\Delta^{*}\right) d \Delta^{*}\right]=$ 0 .

The finding that a change in the expenditure of the domestic household on foreign acquisitions does not affect the interest rate can be explained as follows. Consider an increase in the number of foreign acquisitions. This implies that the revenue from selling firms accruing to the foreign household in the first period increases. The foreign household invests this additional cash flow in the international credit market because, at a given interest rate, it is optimal to hold first period consumption constant. The domestic household, in contrast, needs additional cash to finance the acquisition and therefore reduces credit market investment by the same amount. As a result, the interest rate remains constant. Effectively, the domestic households borrow from the foreign households in order to buy assets previously owned by these households. Lemma 1 also implies that the interest rate would not be affected by changes in domestic or foreign corporate or dividend tax rates.

\section{Tax policy}

Our main interest is to investigate the role of residence and source based taxes in the case of uncoordinated tax policies and the scope for welfare enhancing tax coordination. In our model, governments levy taxes mainly to finance the provision of public consumption goods. But taxes also affect investment behaviour and, therefore, acquisition prices and the interest rate. Countries may be interested to change these prices in order to increase national income or to maximize welfare. 
Public expenditure of the domestic country is given by

$G=S(1+r) t+(\tau+\theta(1-\tau))\left[m \varepsilon+\int_{\Delta^{c}}^{\Delta^{+}} \Delta d \Delta\right]+\theta \int_{\Delta^{* c}}^{\Delta^{*+}}\left(\varepsilon^{*}+\Delta^{*}\right)\left(1-\tau^{*}\right) d \Delta^{*}$

The first term on the right hand side of (14) is revenue from the residence based tax on interest income, the second term stands for revenue from taxing domestic firms and the third term is revenue raised by the residence based tax on foreign dividends. The public sector budget constraint of the foreign country is given by

$G^{*}=S^{*}(1+r) t^{*}+\left(m^{*}-\int_{\Delta^{* c}}^{\Delta^{*+}} d \Delta^{*}\right) \varepsilon^{*}\left[\tau^{*}+\theta^{*}\left(1-\tau^{*}\right)\right]+\tau^{*} \int_{\Delta^{* c}}^{\Delta^{*+}}\left(\varepsilon^{*}+\Delta^{*}\right) d \Delta^{*}$

The budget constraint of the foreign government differs from that of the domestic government in that there is no revenue from taxing dividends from firms located in the domestic country and that the corporate tax partly falls on firms owned by residents of the domestic country. However, as will be discussed further below, taxing these firms at source will reduce the prices at which these firms are acquired, so that the tax burden will ultimately be borne by residents of the foreign country.

In the following, we start by considering the optimal policy choices with respect to the source based corporate income tax and then turn to residence based taxes. The objective of the analysis is to analyse the role of the different taxes under tax competition and to investigate the scope for welfare enhancing tax coordination. Under tax competition, the domestic government sets its tax instruments to maximise the welfare of the domestic household, $W=u\left(C_{1}\right)+C_{2}+H(G)$, and the foreign government maximizes the foreign household's welfare, $W^{*}=$ $u^{*}\left(C_{1}^{*}\right)+C_{2}^{*}+H^{*}\left(G^{*}\right)$. Each country's government takes as given the tax policy of the other country. Tax coordination will be discussed further below. 


\subsection{Source based taxes}

We start by considering the source based corporate income tax. The first order condition for the optimal domestic corporate tax rate can be written as

$$
\frac{\partial W}{\partial \tau}=\left(H^{\prime}-1\right)(1-\theta)\left[m \varepsilon+\int_{\Delta^{c}}^{\Delta^{+}} \Delta d \Delta\right]=0
$$

which implies that the marginal utility of public consumption equals the marginal utility of private consumption $\left(H^{\prime}=1\right)$. The reason is that the domestic tax affects neither savings nor M\&A investment. The factors driving the corporate tax policy of the foreign country are slightly more complex. The first order condition is given by

$$
\begin{aligned}
\frac{\partial W^{*}}{\partial \tau^{*}}= & \left(H^{* \prime}-1\right)\left(m^{*}-\int_{\Delta^{* c}}^{\Delta^{*+}} d \Delta^{*}\right) \varepsilon^{*}\left(1-\theta^{*}\right) \\
& +H^{* \prime} \int_{\Delta^{* c}}^{\Delta^{*+}}\left(\varepsilon^{*}+\Delta^{*}\right) d \Delta^{*}-u^{* \prime} \int_{\Delta^{* c}}^{\Delta^{*+}} \frac{\left(\varepsilon^{*}+\Delta^{*}\right)(1-\theta)}{(1+r)(1-t)} d \Delta^{*}=0
\end{aligned}
$$

The first term on the right hand side of (17) represents the redistribution of funds from foreign firms (first term) owned by foreign households to the foreign government. The second term stands for the welfare effect of taxing firms owned by the domestic household. The third term reflects that a higher corporate tax reduces the acquisition prices received by foreign households who sell their firms in period 1. Whether or not $H^{* \prime}-1>0$ holds is ambiguous and depends on the structure of residence based taxes. ${ }^{5}$

\subsection{Residence based taxes}

Governments may levy residence based taxes on the two types of investment income in our model: dividends from firm ownership and interest income from credit market investment. The first order condition for the optimal domestic tax on

\footnotetext{
${ }^{5}$ It is straightforward to show that a necessary and sufficient condition for $H^{* \prime}-1>0$ to hold is that the sum of the second and third term of (17) is negative. Using $u^{* \prime}=(1+r)\left(1-t^{*}\right)$, this is given if $t^{*}+\theta\left(1-t^{*}\right)<t$.
} 
interest income can be written as

$$
\begin{aligned}
\frac{\partial W}{\partial t}= & -(1+r) \int_{\Delta^{* c}}^{\Delta^{*+}} P^{*}\left(\Delta^{*}\right) d \Delta^{*} \\
& +H^{\prime}\left[(1+r) t \frac{\partial S}{\partial t}-\theta\left(\varepsilon^{*}+\Delta^{* c}\right)\left(1-\tau^{*}\right) \frac{\partial \Delta^{* c}}{\partial t}\right]+\frac{\partial W}{\partial r} \frac{\partial r}{\partial t}=0
\end{aligned}
$$

where we use $H^{\prime}=1$ derived from equation (16), $\frac{\partial P^{*}\left(\Delta^{*}\right)}{\partial t}=\frac{P^{*}\left(\Delta^{*}\right)}{1-t}$ and $\frac{\partial \Delta^{c}}{\partial t}=$ 0 . The first term on the right hand side is negative and reflects that a higher tax on credit market investment increases the willingness of domestic investors to pay for the acquisition of foreign firms. This redistributes income from the domestic economy to the foreign economy. The second term (in square brackets) represents the impact of the portfolio adjustments triggered by the tax change on the government budget. The increase in $t$ will induce households to increase acquisitions and reduce credit market investment (or increase borrowing). Finally, the last term on the right hand side captures the effect of an increasing interest rate (as $\frac{\partial r}{\partial t}>0$, as shown above) on welfare with

$$
\frac{\partial W}{\partial r}=S+(1+r) t \frac{\partial S}{\partial r}+(1-t) \int_{\Delta^{* c}}^{\Delta^{*+}} P^{*}\left(\Delta^{*}\right) d \Delta^{*}
$$

where we use $\frac{\partial P^{*}\left(\Delta^{*}\right)}{\partial r}=-\frac{P^{*}\left(\Delta^{*}\right)}{1+r}$. Whether or not the domestic economy benefits from an increase in the interest rate depends, among other things, on whether it imports or exports capital.

How does the foreign country set its tax on interest income? The first order condition for $t^{*}$ is given by

$$
\begin{aligned}
\frac{\partial W^{*}}{\partial t^{*}}= & \left(H^{* \prime}-1\right) S^{*}(1+r) \\
& +H^{* \prime}\left[(1+r) t^{*} \frac{\partial S^{*}}{\partial t^{*}}+\left(\varepsilon^{*} \theta^{*}\left(1-\tau^{*}\right)-\tau^{*} \Delta^{* c}\right) \frac{\partial \Delta^{* c}}{\partial t^{*}}\right]+\frac{\partial W^{*}}{\partial r} \frac{\partial r}{\partial t^{*}}=0
\end{aligned}
$$

where we use $\frac{\partial P^{*}\left(\Delta^{*}\right)}{\partial t^{*}}=0$. The first term on the right hand side of (20) stands for the welfare effect of shifting funds from the private to the public sector (as long as $H^{* \prime}>1$ ). The second term describes the impact of tax induced portfolio restructuring on the government budget. Essentially, fewer firms will be sold to 
investors from the domestic country which implies that credit market investment declines, so that revenue from the residence based tax on interest income decreases, too. ${ }^{6}$ Decreasing foreign acquisitions are associated with an increased foreign revenue from taxing dividends as more firms remain in foreign ownership and with a decline in corporate tax revenue as long as the the marginal acquisition yields a positive synergy, i.e. $\Delta^{* c}>0$. The effect of an increase in interest rates on foreign welfare is given by

$$
\frac{\partial W^{*}}{\partial r}=S^{*}\left(1+\left(H^{* \prime}-1\right) t^{*}\right)+H^{* \prime}(1+r) t^{*} \frac{\partial S^{*}}{\partial r}-\left(1-t^{*}\right) \int_{\Delta^{* c}}^{\Delta^{*+}} P^{*}\left(\Delta^{*}\right) d \Delta^{*}
$$

Consider next the tax on dividends. The first order condition for the optimal domestic dividend tax can be written as

$\frac{\partial W}{\partial \theta}=\frac{(1-t)(1+r)}{1-\theta} \int_{\Delta^{* c}}^{\Delta^{*+}} P^{*}\left(\Delta^{*}\right) d \Delta^{*}+H^{\prime}\left[(1+r) t \frac{\partial S}{\partial \theta}-\theta\left(\varepsilon^{*}+\Delta^{* c}\right)\left(1-\tau^{*}\right) \frac{\partial \Delta^{* c}}{\partial \theta}\right]=0$

The first term on the right hand side of $(22)$ is positive and reflects that the dividend tax reduces the willingness of domestic investors to pay for foreign firms which reduces their price. The second term reflects the impact of the change in the household's portfolio structure on the government budget constraint. It turns out that, at least for $t \geq 0$, the optimal domestic dividend tax is unambiguously positive, despite of $H^{\prime}=1$. The reason is that the government wants to strategically reduce acquisition prices and, if $t>0$, gains from an increase in credit market investment.

The foreign country's optimal dividend tax policy is implied by

$$
\begin{aligned}
\frac{\partial W^{*}}{\partial \theta^{*}}= & \left(H^{* \prime}-1\right)\left[\left(m^{*}-\int_{\Delta^{* c}}^{\Delta^{*+}} d \Delta^{*}\right) \varepsilon^{*}\left(1-\tau^{*}\right)\right] \\
& +H^{* \prime}\left[(1+r) t^{*} \frac{\partial S^{*}}{\partial \theta^{*}}+\left(\varepsilon^{*} \theta^{*}\left(1-\tau^{*}\right)-\tau^{*} \Delta^{* c}\right) \frac{\partial \Delta^{* c}}{\partial \theta^{*}}\right]=0
\end{aligned}
$$

The foreign government cannot use its dividend tax to strategically manipulate

\footnotetext{
${ }^{6}$ It cannot be excluded that the optimal tax $t^{*}$ is negative. In this case, a decline in $S$ would of course increase tax revenue net of subsidies.
} 
acquisition prices because acquisition prices are determined by the willingness to pay of domestic investors and therefore do not depend on $\theta^{*}$, see equation (3). Thus, the optimal foreign dividend tax will depend on the scarcity of public relative to private funds $\left(H^{* \prime}-1\right)$ and the impact of the portfolio restructurings caused by a change in this tax on the government budget.

\subsection{Coordination of source based taxes}

Are tax policies emerging under tax competition optimal for the economy as a whole? Or is there scope for welfare enhancing tax coordination? At a more general level, is the need for tax coordination related to source or residence based taxation? To answer these questions, we start by considering coordination of the source based corporate income tax holding all other policy variables constant. As the literature shows (see e.g. Bucovetsky, 1991), coordination experiments in an asymmetric setting is a complex issue. Fortunately, these complexities can be dealt with in our framework with regard to source based taxation. Here, our main result is the following

Proposition 2 i) In the absence of residence based taxes on dividends $(\theta=0)$, there is no scope for welfare enhancing coordination of the source based corporate income tax. Tax competition leads to nationally and globally optimal tax levels.

ii) If dividend taxes are positive $(\theta>0)$, a coordinated increase in source based corporate income taxes, departing from the equilibrium without coordination, decreases welfare.

Proof. We consider a coordinated marginal change in the domestic and the foreign corporate tax rates, departing from the equilibrium under tax competition and holding all other policy instruments $\left(t, t^{*}, \theta\right.$ and $\left.\theta^{*}\right)$ constant. The change in domestic welfare is $d W=\frac{\partial W}{\partial \tau} d \tau+\frac{\partial W}{\partial \tau^{*}} d \tau^{*}$. Since the equilibrium under tax competition implies $\frac{\partial W}{\partial \tau}=0$, the welfare effect can be expressed as

$$
d W=\frac{\partial W}{\partial \tau^{*}} d \tau^{*}=-H^{\prime} \theta \int_{\Delta^{* c}}^{\Delta^{*+}}\left(\varepsilon^{*}+\Delta^{*}\right) d \tau^{*}
$$


which equals zero for $\theta=0$. Likewise, we can derive the effect on the welfare of the foreign country as $d W^{*}=\frac{\partial W^{*}}{\partial \tau} d \tau=0$.

The result in proposition 2 may be explained as follows. Given that there is only M\&A investment and credit market investment in our model, international capital flows do not involve a relocation of real capital from one country to another. Moreover, the domestic household is not limited in the number of acquisitions. As a consequence, the marginal synergy is zero, tax payments under the original owner and the acquirer are equal and corporate tax rate changes have no impact on M\&A investment. If $\theta>0$, corporate taxes are inefficiently high under tax competition, i.e. a tax rate cut gives rise to positive fiscal externalities. This happens because a cut in the foreign corporate tax rate increase the dividends after foreign taxes. As a result, domestic tax revenue increases.

It is interesting to contrast the fiscal externalities arising in our model to the fiscal externalities arising in models of tax competition with greenfield investment. In the case of greenfield investment, a corporate tax rate cut in one country increases capital demand in that country. Savings available for the creation of new production facilities become scarcer, so that the interest rate increases. As a result of this, greenfield investment in other jurisdictions declines, and savings from these jurisdictions flow to the jurisdiction which has reduced its tax rate. If these jurisdictions levy a source based tax on the marginal greenfield investment, they lose tax revenue. Therefore tax rate cuts give rise to negative fiscal externalities. However, if they also levy a residence based tax on savings, the increase of the interest rate caused by the tax cut in the other jurisdiction raises revenue from the residence based tax on savings. This mitigates the negative fiscal externality of corporate tax rate cuts. In so far, residence based taxes on capital income tend to reduce the need for tax coordination.

\subsection{Coordination of residence based taxes}

In the previous section, we have shown that tax competition in source based corporate taxes may effectively lead to efficient outcomes. We did so by showing that a small increase in $\tau$ and $\tau^{*}$ holding all other policy instruments constant has no welfare effect if $\theta=0$ and has negative welfare effects if $\theta>0$. In the following, 
we analyse an equivalent experiment for $t$ and $t^{*}$.

To start, consider a small increase in the foreign tax rate $t^{*}$ on domestic welfare.

$$
\frac{\partial W}{\partial t^{*}}=-H^{\prime} \theta\left(\varepsilon^{*}+\Delta^{* c}\right)\left(1-\tau^{*}\right) \frac{\partial \Delta^{* c}}{\partial t^{*}}+\frac{\partial W}{\partial r} \frac{\partial r}{\partial t^{*}}
$$

where we used $\frac{\partial \Delta^{c}}{\partial t^{*}}=0$ and $\frac{\partial P^{*}\left(\Delta^{*}\right)}{\partial t^{*}}=0$. An increase in $t^{*}$ reduces the foreign household's incentive to save and increases the present value of future income from firm profits and, thus, the minimum selling price for the marginal target firm. As a consequence, acquisitions are reduced which decreases dividend tax revenue (first term). Moreover, the interest rate is increased which affects the domestic household's welfare according to equation (19). If $S<0$, then $\partial W / \partial r$ has an ambiguous sign.

Similarly, an increase in $t$ affects foreign welfare by

$$
\frac{\partial W^{*}}{\partial t}=(1+r)\left(\frac{1-t^{*}}{1-t}\right) \int_{\Delta^{* c}}^{\Delta^{*+}} P^{*}\left(\Delta^{*}\right) d \Delta^{*}+H^{* \prime}\left(\varepsilon^{*} \theta^{*}\left(1-\tau^{*}\right)-\tau^{*} \Delta^{* c}\right) \frac{\partial \Delta^{* c}}{\partial t}+\frac{\partial W^{*}}{\partial r} \frac{\partial r}{\partial t}
$$

where we have used $\frac{\partial P^{*}\left(\Delta^{*}\right)}{\partial t}=\frac{P^{*}\left(\Delta^{*}\right)}{1-t}$. The first term captures the increase in intramarginal acquisition prices in response to rising domestic income taxes. The reason for this effect is that an increase in $t$ makes saving less attractive than acquiring firms. This increases demand for target firms. The second term seizes the change in tax revenue due to an increase in foreign acquisitions, $\partial \Delta^{* c} / \partial t<0$. Dividend tax revenue is reduced and corporate tax revenue is increased as long as the marginal synergy $\Delta^{* c}$ is positive. Finally, increasing interest rates (see Lemma) affect welfare according to equation (21), which has an ambiguous sign.

Both externalities are ambiguous in sign. As mentioned above, tax coordination in an asymmetric setting raises some complexities, as has been previously noted in the tax competition literature, see e.g. Bucovetsky (1991). The main complexity arising in our model is that a symmetric increase in tax rates, starting from an asymmetric equilibrium, leads to a change in the relative tax prices of acquisitions, see equation (5). For instance, increasing $t$ and $t^{*}$ by the same amount reduces the cut-off level $\Delta^{c *}$ (increases foreign acquisitions) if $t>t^{*}$ and vice versa. This effect on the relative tax price makes the coordination effects dependent on the 
(relative) size of the tax rates in the initial equilibrium. In general, coordination effects then become ambiguous. There are two ways of dealing with this issue. Firstly, we could add a second sector in which foreign households acquire target firms to have a symmetric model with identical equilibrium tax rates. It is straightforward to show that our key results remain robust, but the notation becomes much more cumbersome. Secondly, we may consider asymmetric tax coordination experiments, i.e. coordinated tax increases which leave the relative tax prices unaffected. In the following, we will pursue this second strategy, mainly to keep the exposition simple.

Therefore, let both countries increase their tax rates such that the relative tax price $\frac{1-t}{1-t^{*}}$ stays constant which requires $d t=\frac{1-t}{1-t^{*}} d t^{*}$. As a consequence, the allocation of ownership (i.e. the number of acquisitions in each country) remains unaffected.

How do savings and the interest rate react to such a tax reform? It follows from $S+S^{*}=0$ that $\frac{\partial S}{\partial r} d r+\frac{\partial S}{\partial t} d t+\frac{\partial S^{*}}{\partial r} d r+\frac{\partial S^{*}}{\partial t^{*}} d t^{*}=0$. With $\frac{\partial S}{\partial r}=-\frac{1-t}{u^{\prime \prime}}, \frac{\partial S^{*}}{\partial r}=-\frac{1-t^{*}}{u^{* \prime \prime}}$, $\frac{\partial S}{\partial t}=\frac{1+r}{u^{\prime \prime}}, \frac{\partial S^{*}}{\partial t^{*}}=\frac{1+r}{u^{* \prime \prime}}$ and $d t=\frac{1-t}{1-t^{*}} d t^{*}=d \bar{t}$, it follows $\frac{d r}{d \bar{t}}=\frac{1+r}{1-t}$. Domestic saving is affected by $\frac{d S}{d \bar{t}}=\frac{\partial S}{\partial t}+\frac{\partial S}{\partial r} \frac{d r}{d \bar{t}}=\frac{1+r}{u^{\prime \prime}}-\frac{1-t}{u^{\prime \prime}} \frac{1+r}{1-t}=0$. It is straightforward to show that $\frac{d S^{*}}{d t^{*}}=0$ as well. The overall effect is then given by $d\left(W+W^{*}\right)=$ $\left(\frac{\partial W}{\partial t}+\frac{\partial W^{*}}{\partial t}\right) d \bar{t}+\left(\frac{\partial W}{\partial t^{*}}+\frac{\partial W^{*}}{\partial t^{*}}\right) \frac{1-t^{*}}{1-t} d \bar{t}$ or

$$
\frac{d\left(W+W^{*}\right)}{d \bar{t}}=\left(H^{* \prime}-H^{\prime}\right) S^{*}\left(\frac{1+r}{1-t}\right)
$$

We summarize this in

Proposition 3 Departing from the uncoordinated equilibrium, a coordinated increase in $t$ and $t^{*}$ which leaves the number of acquisitions in each country unaffected, i.e. $d t=\frac{1-t}{1-t^{*}} d t^{*}$, increases welfare if $H^{* \prime}-H^{\prime}>0$ and $S^{*}=-S>0$.

This proposition shows that a coordinated increase in $t$ and $t^{*}$ mainly redistributes funds among the two jurisdictions.

\subsection{Tax coordination in taxes on dividends}

How do changes in dividend taxes affect the neighbour countries? Again, we start with considering the effect of a small increase in the foreign policy parameter on 
domestic welfare, holding all other policy parameters constant.

$$
\frac{\partial W}{\partial \theta^{*}}=H^{\prime}\left[(1+r) t \frac{\partial S}{\partial \theta^{*}}-\theta\left(\varepsilon^{*}+\Delta^{* c}\right)\left(1-\tau^{*}\right) \frac{\partial \Delta^{* c}}{\partial \theta^{*}}\right]
$$

with $\frac{\partial \Delta^{* c}}{\partial \theta^{*}}=-\varepsilon^{*}\left(\frac{1}{1-\theta}\right)\left(\frac{1-t}{1-t^{*}}\right)<0$. Increasing $\theta^{*}$ reduces the minimum selling price of the foreign owners and, thus, increases the number of foreign acquisitions. This reduces domestic savings (or increases domestic borrowing) and thus decreases revenue from interest income taxation. In addition, if there is a positive tax rate on dividends, tax revenue from this source is increased. Note that $\theta^{*}$ has no impact on the interest rate $r .^{7}$

Now, consider the effect of a small increase in $\theta$ on foreign welfare.

$$
\begin{aligned}
\frac{\partial W^{*}}{\partial \theta}= & -\frac{(1+r)\left(1-t^{*}\right)}{1-\theta} \int_{\Delta^{* c}}^{\Delta^{*+}} P^{*}\left(\Delta^{*}\right) d \Delta^{*} \\
& +H^{* \prime}\left[(1+r) t^{*} \frac{\partial S^{*}}{\partial \theta}+\left(\varepsilon^{*} \theta^{*}\left(1-\tau^{*}\right)-\tau^{*} \Delta^{* c}\right) \frac{\partial \Delta^{* c}}{\partial \theta}\right]
\end{aligned}
$$

Increasing $\theta$ reduces the price the domestic investor is willing to pay for the target firm. As a consequence, all purchase prices are reduced. In addition, rising dividend taxes reduce the demand for foreign acquisitions and, thus, the need for foreign savings. This reduces revenue from interest income taxation. Finally, the decrease in foreign acquisitions increases foreign dividend tax revenue but reduces corporate tax revenue if the marginal synergy is positive.

Again, both externalities have ambiguous signs. We therefore consider an experiment equivalent to the one in the previous section. Let both countries increase their dividend tax rates such that the relative dividend tax price $\frac{1-\theta}{1-\theta^{*}}$ stays constant which requires $d \theta=\frac{1-\theta}{1-\theta^{*}} d \theta^{*}=d \bar{\theta}$. Consequently, the number of foreign acquisitions remains unaffected. The effect on global welfare is given by

$$
\begin{aligned}
\frac{d\left(W+W^{*}\right)}{d \bar{\theta}}= & \left(H^{* \prime}-1\right) \frac{1-\theta^{*}}{1-\theta}\left[\left(m^{*}-\int_{\Delta^{* c}}^{\Delta^{*+}} d \Delta^{*}\right) \varepsilon^{*}\left(1-\tau^{*}\right)\right] \\
& +\frac{\left(t^{*}-t\right)(1+r)}{1-\theta} \int_{\Delta^{* c}}^{\Delta^{*+}} P^{*}\left(\Delta^{*}\right) d \Delta^{*}
\end{aligned}
$$

\footnotetext{
${ }^{7}$ It is straightforward to show that the externality on domestic welfare is positive if $t<\theta$.
} 
We summarize this in

Proposition 4 Departing from the uncoordinated equilibrium, a simultaneous increase of $\theta$ and $\theta^{*}$ such that the number of foreign acquisitions remains constant, i.e. $d \theta=\frac{1-\theta}{1-\theta^{*}} d \theta^{*}$, increases welfare if $H^{* \prime}-1>0$ and $t^{*}-t \geq 0$ and, otherwise, if the tax difference $t-t^{*}$ is sufficiently small.

The above three propositions 2 to 4 suggest that, if investment takes the form of M\&A and the number of acquisitions is unlimited, source based taxes are inefficiently high and residence based taxes are - under mild symmetry requirements - inefficiently low. In the following, we consider the case in which the number of acquisitions is limited.

\subsection{Extension: Limited number of acquisitions}

A crucial assumption for the above analysis is that the number of M\&A transactions is not limited. As a consequence, investors acquire target firms until the marginal after-tax surplus is zero. In the following, we will assume that the number of acquisitions is constrained to a certain number $N$. Possible reasons are scarce management capacities, boundaries to firm size etc. In any way, it captures the idea that the marginal acquisition yields a positive surplus. At the margin, investors make a discrete investment choice between the domestic and the foreign location, which has an equivalent in the analysis of greenfield investment choices, see Devereux \& Griffith (2003).

The above model is modified by adding the additional assumption of $\int_{\Delta^{c}}^{\Delta^{+}} d \Delta+$ $\int_{\Delta^{* c}}^{\Delta^{*+}} d \Delta^{*}=N$ from which follows $d \Delta^{c}=-d \Delta^{* c}$. Investment is profit-maximizing if

$$
\Delta^{* c}=\Delta^{c}\left(\frac{1-\tau}{1-\tau^{*}}\right)+\varepsilon^{*}\left[\frac{(1-t)\left(1-\theta^{*}\right)}{\left(1-t^{*}\right)(1-\theta)}-1\right]
$$

from which follows that source based taxes are no longer neutral. Domestic corporate taxes increase the number of foreign acquisitions $\frac{d \Delta^{* c}}{d \tau}=-\frac{\Delta^{c}}{2-\tau-\tau^{*}}=$ $-\frac{d \Delta^{c}}{d \tau}$ and foreign taxes do the opposite, $\frac{d \Delta^{* c}}{d \tau^{*}}=\left(\frac{1-\tau}{1-\tau^{*}}\right) \frac{\Delta^{c}}{2-\tau-\tau^{*}}=-\frac{d \Delta^{c}}{d \tau^{*}}$. The effects of taxes on interest income and dividends are equivalent to those derived in the model above. 
Optimal corporate tax policy of the domestic country is given $\frac{\partial W}{\partial \tau}=0$ and $\frac{\partial W^{*}}{\partial \tau^{*}}=0$, see the appendix. What are the externalities of corporate taxation in this setting? Consider first a small increase in the foreign tax rate and its effect on domestic welfare:

$$
\begin{aligned}
\frac{\partial W}{\partial \tau^{*}}= & H^{\prime}(1+r) t \frac{\partial S}{\partial \tau^{*}}-H^{\prime} \int_{\Delta^{* c}}^{\Delta^{*+}} \theta\left(\varepsilon^{*}+\Delta^{*}\right) d \Delta^{*} \\
& -H^{\prime}\left[\theta\left(\varepsilon^{*}+\Delta^{* c}\right)\left(1-\tau^{*}\right) \frac{\partial \Delta^{* c}}{\partial \tau^{*}}+(\tau+\theta(1-\tau)) \Delta^{c} \frac{\partial \Delta^{c}}{\partial \tau^{*}}\right]
\end{aligned}
$$

An increase in $\tau^{*}$ decreases the number of foreign acquisitions and, thus, decreases the need for external finance, as $\partial S / \partial \Delta^{* c}=P^{*}\left(\Delta^{* c}\right)>0$, which increases the revenue from taxes on interest income. The second term captures the negative effect of an increase in $\tau^{*}$ on the domestic dividend tax base. Furthermore, the foreign corporate tax rate decreases firm income in period 2. However, it also reduces acquisition prices in period 1 which fully compensates for the income loss in period 2. The third effect captures the change in tax revenue due to the reallocation of international acquisitions. The overall effect is ambiguous.

Now, consider the effect of a small increase of $\tau$ on foreign welfare:

$$
\begin{aligned}
\frac{\partial W^{*}}{\partial \tau}= & H^{* \prime}(1+r) t^{*} \frac{\partial S^{*}}{\partial \tau}-\left[u^{* \prime} P\left(\Delta^{* c}\right)-\varepsilon^{*}\left(1-\tau^{*}\right)\left(1-\theta^{*}\right)\right] \frac{\partial \Delta^{* c}}{\partial \tau} \\
& +H^{* \prime}\left(\left(1-\tau^{*}\right) \varepsilon^{*} \theta^{*}-\tau^{*} \Delta^{* c}\right) \frac{\partial \Delta^{* c}}{\partial \tau}
\end{aligned}
$$

An increase in $\tau$ increases the number of foreign acquisitions which increases the domestic need for foreign financial funds, as $\partial S^{*} / \partial \Delta^{* c}=-P^{*}\left(\Delta^{* c}\right)<0$. This increases revenue from taxing interest income (first term). Furthermore, it decreases income from selling firms in period 1 and reduces firm income in period 2. The net effect can be shown to be strictly positive. ${ }^{8}$ Finally, the increase in foreign acquisition reduces foreign dividend tax revenue and increases revenue from taxing the marginal synergy $\Delta^{* c}$.

Since the externalities are different for both countries, the question arises whether a coordinated increase of $\tau$ and $\tau^{*}$ increases welfare or reduces it. Due to

\footnotetext{
${ }^{8}$ It can be shown that $u^{* \prime} P\left(\Delta^{* c}\right)-\varepsilon^{*}\left(1-\tau^{*}\right)\left(1-\theta^{*}\right)=\frac{\left(1-t^{*}\right)}{(1-t)} \Delta^{c}(1-\tau)(1-\theta)>0$.
} 
the asymmetry of countries, we consider a coordination experiment similar to those analysed above. Let both countries increase their corporate tax rate such that the allocation of ownership remains unaffected, i.e. $d \tau=\left(\frac{1-\tau}{1-\tau^{*}}\right) d \tau^{*}=d \bar{\tau}$, which implies that $\Delta^{c}, \Delta^{* c}, S$ and $S^{*}$ remain constant. Then, world welfare $W+W^{*}$ changes as follows:

$$
\begin{aligned}
\frac{d\left(W+W^{*}\right)}{d \bar{\tau}}= & \left(H^{\prime}-1\right)(1-\theta)\left(m \varepsilon+\int_{\Delta^{c}}^{\Delta^{+}} \Delta d \Delta\right) \\
& +\left(H^{* \prime}-1\right)\left[\left(m^{*}-\int_{\Delta^{* c}}^{\Delta^{*+}} d \Delta^{*}\right) \varepsilon^{*}\left(1-\theta^{*}\right)+\int_{\Delta^{* c}}^{\Delta^{*+}}(1-\theta)\left(\varepsilon^{*}+\Delta^{*}\right) d \Delta^{*}\right] \\
& +\left(\theta\left(H^{* \prime}-H^{\prime}\right)+\frac{t^{*}-t}{1-t}(1-\theta)\right) \int_{\Delta^{* c}}^{\Delta^{*+}}\left(\varepsilon^{*}+\Delta^{*}\right) d \Delta^{*}
\end{aligned}
$$

which is positive as long as asymmetries, measured by $t-t^{*}$ and $H^{\prime}-H^{* \prime}$, do not become too severe. Thus, if the number of acquisitions is limited for some reason, the effect of coordination is similar to the one in the case of greenfield investment.

\subsection{Extension: Capital gains taxes and tax depreciation of goodwill}

So far, we have assumed that the proceeds from selling the firm are exempt from tax and that the acquirer cannot write off the purchase price. Assume now that there is a capital gains tax denoted by $c$, and further that the acquirer gets a corporate tax deduction $\delta$ of the purchase price in period $1 .^{9}$ In this case, the maximum acquisition price for foreign acquisition would be given by

$$
(1+r)(1-t) P^{*}\left(\Delta_{j}^{*}\right)\left(1-\delta \tau^{*}\right)=\left(\varepsilon^{*}+\Delta_{j}^{*}\right)\left(1-\tau^{*}\right)(1-\theta)
$$

which is the equivalent to equation (3). The vendor would be indifferent between selling and not selling if

$$
(1+r)\left(1-t^{*}\right) P^{*}\left(\Delta_{j}^{*}\right)\left(1-c^{*}\right) \geq \varepsilon^{*}\left(1-\tau^{*}\right)\left(1-\theta^{*}\right)
$$

${ }^{9}$ All other assumptions are as in the base version of the model. 
This yields the cutoff value

$$
\Delta^{c *}=\varepsilon^{*}\left[\frac{\left(1-\theta^{*}\right)(1-t)\left(1-\delta \tau^{*}\right)}{(1-\theta)\left(1-t^{*}\right)\left(1-c^{*}\right)}-1\right]
$$

If the capital gains tax is equal to the corporate income tax rate and the purchase price is fully deductible, i.e. $\left(1-\delta \tau^{*}\right) /\left(1-c^{*}\right)=1$, the results derived in the preceding section would be preserved. If there are asymmetries, i.e. if $\left(1-\delta \tau^{*}\right) /\left(1-c^{*}\right) \neq 1$, acquisitions are distorted. However, it is straightforward to show that our results concerning the need for corporate tax coordination also hold in this case.

\section{Discussion of the results}

How are the results derived in the two preceding sections related to the literature on tax competition and tax coordination? In standard models of tax competition with greenfield investment, an increase in source based capital income taxes induces a capital flow to other jurisdictions. If these jurisdictions tax the marginal greenfield investment, they benefit from this capital inflow, i.e. a positive fiscal externality arises. Things are different if residence and source based taxes coexist. In most models of greenfield investment with residence based capital income taxes, the welfare gains from a coordination of source based taxes are small or even disappear, see Bucovetsky and Wilson (1991). In the baseline version of our model, quite the opposite is true. In the absence of residence based taxes, there is no need for corporate tax coordination, but as soon as residence based taxes exist, a case for tax coordination can be made. The fact that the bulk of foreign direct investment is actually M\&A suggests that residence based taxes should receive more attention in international tax coordination initiatives.

As discussed above, a crucial assumption of our results concerns limitations in the number of acquisitions. As our purpose is to build a model which serves as an equivalent to the standard model of greenfield investment, the question arises if and how the number of investment projects is limited in the standard model. In an open economy, the number of greenfield investment projects may have three kinds of limits, firstly the available amount of saving, secondly the decreasing returns to 
capital in a given location and, thirdly, a limitation in the number of investment projects per firm. The latter is similar to the one assumed in section 3.6. The second limit has an equivalent in our model in the decreasing synergy $\left(\Delta, \Delta^{*}\right)$ of target firms. At the margin, a greenfield project's return net of the cost of capital is zero as is an acquisition's after-tax synergy. A crucial difference occurs at the first limit which does not hold for acquisitions. Whereas greenfield investment absorbs savings, acquisitions just redistribute savings. Capital invested in a greenfield project cannot be used elsewhere whereas the proceeds from selling the firm may be invested at the world capital market. In the light of these arguments, we would like to propose that the baseline version of our model may be considered as an equivalent to the standard model of greenfield investment where the marginal return just covers the cost of capital, whereas the model analysed in section 3.6 may serve as an equivalent to the greenfield model of discrete investment choices, as in Devereux and Griffith (2003).

It is also interesting to discuss our results in the light of the view developed in Desai and Hines (2004) who argue that, since M\&A investment abroad does not reduce the domestic capital stock, a tax policy which is based on this assumption is necessarily misguided. As a consequence, governments should exempt foreign income from tax because an additional tax upon repatriation distorts ownership decision and leads to efficiency losses. Our analysis confirms that taking into account M\&A investment changes the implications for tax policy substantially. However, we also show that differences in residence based do not need to distort ownership decisions, see equation (3).

Our results are also related to the literature on the capitalization of taxes in land prices (see Mieszkowski, 1972, or Hamilton, 1976). Source based taxes are neutral for the number of acquisitions because any tax change will be fully capitalized in acquisition prices. This happens because target firms are immobile by assumption and therefore cannot escape taxation by relocating abroad. The comparison with the literature on land prices also points to a limitation of our analysis: We do not discuss the initial investment decisions that created the target firms. Adding this decision would introduce elements of greenfield investment into the model. The key tax effects related to mergers and acquisitions derived in our model would remain, but they would come out much less clearly. 


\section{Conclusions}

This paper develops a framework designed to analyse the role of source and residence based taxes for tax competition and tax coordination in a world where investment takes the form of M\&A investment rather than greenfield investment. In the base version of our model, domestic entrepreneurs acquire domestic and foreign firms to exploit synergies. An acquisition does not imply a change in the stock of a firm's real capital, just a change in ownership. The governments levy source based taxes on corporate profits and residence based taxes on dividends and interest income. If the number of potential acquisitions is unlimited, source based taxes do not affect M\&A investment. One reason is that M\&A investment does not absorb savings, in contrast to greenfield investment.

We find that, if governments can only levy source based taxes, the tax levels they choose under tax competition are also efficient for the economy as a whole, which implies that there is no room for welfare enhancing tax coordination. The reason is that a change in the source based tax in one country does not affect M\&A investment in other countries, i.e. no fiscal externalities arise. In contrast, if there are residence based taxes, competition in source based taxes gives rise to negative fiscal externalities which imply inefficiently high tax rates in equilibrium.

These results contrast with findings for tax competition for greenfield investment, where source based taxes are usually seen as the major source of fiscal externalities. The availability of residence based taxes makes the demand for tax coordination less pressing or even implies that no coordination of source based taxes is necessary any more (Bucovetsky and Wilson, 1991).

If the number of acquisitions is limited for some reason, the implications for tax policy are similar to the case of greenfield investment. Higher source based taxes will give rise to positive fiscal externalities and inefficiently low tax levels are likely to prevail under tax competition.

In terms of policy implications, our results imply that the prevailing view, according to which tax competition leads to inefficiently low levels of source based taxes, has to be qualified. More attention may have to be devoted to the interaction between source and residence based taxes and the impact of taxes on M\&A investment. 


\section{References}

[1] Andrade, G., Mitchell, M. \& Stafford, E. (2001). New Evidence and Perspectives on Mergers, Journal of Economic Perspectives 15(2), 103-120.

[2] Auerbach, A. J. \& Slemrod, J. (1997). The Economic Effects of the Tax Reform Act of 1986, Journal of Economic Literature 35(June): 589-632.

[3] Becker, J. \& Fuest, C. (2008). Tax Competition - Greenfield Investment versus Mergers and Acquisitions, CESifo Working Paper No. 2247.

[4] Becker, J. \& Fuest, C. (forthcoming). Taxing Foreign Profits with International Mergers and Acquisitions, International Economic Review.

[5] Bucovetsky, S. (1991). Asymmetric Tax Competition, Journal of Urban Economics 30(2): 167-181.

[6] Bucovetsky, S. \& Wilson, J. (1991). Tax Competition with Two Tax Instruments, Regional Science and Urban Economics 21(3): 333-350.

[7] Collins, J., Kemsley, D. \& Shackelford, D. (1995). Tax Reform and Foreign Acquisitions: A Microanalysis, National Tax Journal 48(1): 1-21.

[8] Desai, M. A. \& Hines, J. R. (2004). Old Rules and New Realities: Corporate Tax Policy in a Global Setting, National Tax Journal 57(4): 937-60.

[9] Devereux, M. P. (1990). Capital Export Neutrality, Capital Import Neutrality, Capital Ownership Neutrality and All That, Unpublished Working Paper.

[10] Devereux, M. P. (2007). The Impact of Taxation on the Location of Capital, Firms and Profit: A Survey of Empirical Evidence, Oxford University Centre for Business Taxation Working Paper Series No. 07/2.

[11] Devereux, M. P. \& Griffith, R. (2003). Evaluating Tax Policy for Location Decisions, International Tax and Public Finance 10(2): 107-126.

[12] Feldstein, M. \& Hartman, D. (1979). The Optimal Taxation of Foreign Source Investment Income, Quarterly Journal of Economics 93(4): 613-629. 
[13] Fuest, C. \& Huber, B. (2004). Why Do Countries Combine the Exemption System for the Taxation of Foreign Profits with Domestic Double Taxation Relief?, Journal of International Economics 62(1): 219-231.

[14] Fuest, C., Huber, B. \& Mintz, J. (2005). Capital Mobility and Tax Competition: A Survey, Foundations and Trends in Microeconomics 1(1): 1-62.

[15] Gordon, R. H. \& Bovenberg, A. L. (1996). Why is Capital So Immobile Internationally? Possible Explanations and Implications for Capital Income Taxation, American Economic Review 86(5): 1057-1075.

[16] Hamilton, B. W. (1976). Capitalization of Intrajurisdictional Differences in Local Tax Prices, American Economic Review 66: 743-753.

[17] Haufler, A. \& Schulte, C. (2007). Merger Policy and Tax Competition, Working Paper.

[18] Huizinga, H. \& Voget, J. (forthcoming). International Taxation and the Direction and Volume of Cross-Border M\&As, Journal of Finance.

[19] Markusen, J. R. (2002). Multinational Firms and the Theory of International Trade, Massachussets Institute of Technology, Cambridge, USA.

[20] Mieszkowski, P. (1972). The Property Tax: An Excise Tax or a Profits Tax?, Journal of Public Economics 1(1): 73-96.

[21] Richman, P. B. (1963). Taxation of Foreign Investment Income - An Economic Analysis, The Johns Hopkins Press, Baltimore.

[22] Scholes, M. S. \& Wolfson, M. A. (1990). The Effects of Changes in Tax Laws on Corporate Reorganization Activity, Journal of Business 63(1): S141-164.

[23] Swenson, D. L. (1994). The Impact of U.S. Tax Reform on Foreign Direct Investment in the United States, Journal of Public Economics 54(2): 243266. 


\section{Appendix}

The first order conditions for optimal tax policy choices in section 3.6 are given by

$$
\begin{aligned}
\frac{\partial W}{\partial \tau}= & 0=\left(H^{\prime}-1\right)(1-\theta)\left[m \varepsilon+\int_{\Delta^{c}}^{\Delta^{+}} \Delta d \Delta\right]+H^{\prime}(1+r) t \frac{\partial S}{\partial \tau} \\
& -H^{\prime}\left[\theta\left(\varepsilon^{*}+\Delta^{* c}\right)\left(1-\tau^{*}\right) \frac{\partial \Delta^{* c}}{\partial \tau}+(\tau+\theta(1-\tau)) \Delta^{c} \frac{\partial \Delta^{c}}{\partial \tau}\right]
\end{aligned}
$$

and

$$
\begin{aligned}
\frac{\partial W^{*}}{\partial \tau^{*}}= & \left(H^{* \prime}-1\right)\left(m^{*}-\int_{\Delta^{* c}}^{\Delta^{*+}} d \Delta^{*}\right) \varepsilon^{*}\left(1-\theta^{*}\right)+H^{* \prime} \int_{\Delta^{* c}}^{\Delta^{*+}}\left(\varepsilon^{*}+\Delta^{*}\right) d \Delta^{*} \\
& +H^{* \prime}(1+r) t^{*} \frac{\partial S^{*}}{\partial \tau^{*}}-\frac{1-t^{*}}{1-t} \int_{\Delta^{* c}}^{\Delta^{*+}}\left(\varepsilon^{*}+\Delta_{j}^{*}\right)(1-\theta) d \Delta^{*} \\
& -\left[u^{* \prime} P\left(\Delta^{* c}\right)-\varepsilon^{*}\left(1-\tau^{*}\right)\left(1-\theta^{*}\right)\right] \frac{\partial \Delta^{* c}}{\partial \tau^{*}}+H^{* \prime}\left(\left(1-\tau^{*}\right) \varepsilon^{*} \theta^{*}-\tau^{*} \Delta^{* c}\right) \frac{\partial \Delta^{* c}}{\partial \tau^{*}}
\end{aligned}
$$

These two equations are used to derive equation (35). 


\section{CESifo Working Paper Series}

for full list see www.cesifo-group.org/wp

(address: Poschingerstr. 5, 81679 Munich, Germany, office@cesifo.de)

2793 Vidar Christiansen and Stephen Smith, Externality-correcting Taxes and Regulation, September 2009

2794 John Beirne, Guglielmo Maria Caporale, Marianne Schulze-Ghattas and Nicola Spagnolo, Global and Regional Spillovers in Emerging Stock Markets: A Multivariate GARCH-in-mean Analysis, September 2009

2795 Rüdiger Pethig and Frieder Kolleß, Asymmetric Capital-Tax Competition, Unemployment and Losses from Capital Market Integration, September 2009

2796 Ngo Van Long, Horst Raff and Frank Stähler, Innovation and Trade with Heterogeneous Firms, September 2009

2797 Margit Osterloh and Bruno S. Frey, Research Governance in Academia: Are there Alternatives to Academic Rankings?, September 2009

2798 Thiess Buettner and Clemens Fuest, The Role of the Corporate Income Tax as an Automatic Stabilizer, September 2009

2799 Annette Alstadsæter, Measuring the Consumption Value of Higher Education, September 2009

2800 Peter Friedrich, Chang Woon Nam and Janno Reiljan, Local Fiscal Equalization in Estonia: Is a Reform Necessary?, September 2009

2801 Evžen Kočenda and Jan Hanousek, State Ownership and Control in the Czech Republic, September 2009

2802 Michael Stimmelmayr, Wage Inequality in Germany: Disentangling Demand and Supply Effects, September 2009

2803 Biswa N. Bhattacharyay, Towards a Macroprudential Surveillance and Remedial Policy Formulation System for Monitoring Financial Crisis, September 2009

2804 Margarita Katsimi, Sarantis Kalyvitis and Thomas Moutos, "Unwarranted" Wage Changes and the Return on Capital, September 2009

2805 Christian Lessmann and Gunther Markwardt, Aid, Growth and Devolution, September 2009

2806 Bas Jacobs and Dirk Schindler, On the Desirability of Taxing Capital Income to Reduce Moral Hazard in Social Insurance, September 2009

2807 Hans Gersbach and Noemi Hummel, Climate Policy and Development, September 2009 
2808 David E. Wildasin, Fiscal Competition for Imperfectly-Mobile Labor and Capital: A Comparative Dynamic Analysis, September 2009

2809 Johan Eyckmans and Cathrine Hagem, The European Union's Potential for Strategic Emissions Trading through Minimal Permit Sale Contracts, September 2009

2810 Ruediger Bachmann and Christian Bayer, The Cross-section of Firms over the Business Cycle: New Facts and a DSGE Exploration, October 2009

2811 Slobodan Djajić and Michael S. Michael, Temporary Migration Policies and Welfare of the Host and Source Countries: A Game-Theoretic Approach, October 2009

2812 Devis Geron, Social Security Incidence under Uncertainty Assessing Italian Reforms, October 2009

2813 Max-Stephan Schulze and Nikolaus Wolf, Economic Nationalism and Economic Integration: The Austro-Hungarian Empire in the Late Nineteenth Century, October 2009

2814 Emilia Simeonova, Out of Sight, Out of Mind? The Impact of Natural Disasters on Pregnancy Outcomes, October 2009

2815 Dan Kovenock and Brian Roberson, Non-Partisan 'Get-Out-the-Vote' Efforts and Policy Outcomes, October 2009

2816 Sascha O. Becker, Erik Hornung and Ludger Woessmann, Catch Me If You Can: Education and Catch-up in the Industrial Revolution, October 2009

2817 Horst Raff and Nicolas Schmitt, Imports, Pass-Through, and the Structure of Retail Markets, October 2009

2818 Paul De Grauwe and Daniel Gros, A New Two-Pillar Strategy for the ECB, October 2009

2819 Guglielmo Maria Caporale, Thouraya Hadj Amor and Christophe Rault, International Financial Integration and Real Exchange Rate Long-Run Dynamics in Emerging Countries: Some Panel Evidence, October 2009

2820 Saša Žiković and Randall K. Filer, Hybrid Historical Simulation VaR and ES: Performance in Developed and Emerging Markets, October 2009

2821 Panu Poutvaara and Andreas Wagener, The Political Economy of Conscription, October 2009

2822 Steinar Holden and Åsa Rosén, Discrimination and Employment Protection, October 2009

2823 David G. Mayes, Banking Crisis Resolution Policy - Lessons from Recent Experience Which elements are needed for robust and efficient crisis resolution?, October 2009 
2824 Christoph A. Schaltegger, Frank Somogyi and Jan-Egbert Sturm, Tax Competition and Income Sorting: Evidence from the Zurich Metropolitan Area, October 2009

2825 Natasa Bilkic, Thomas Gries and Margarethe Pilichowski, Stay in School or Start Working? - The Human Capital Investment Decision under Uncertainty and Irreversibility, October 2009

2826 Hartmut Egger and Udo Kreickemeier, Worker-Specific Effects of Globalisation, October 2009

2827 Alexander Fink and Thomas Stratmann, Institutionalized Bailouts and Fiscal Policy: The Consequences of Soft Budget Constraints, October 2009

2828 Wolfgang Ochel and Anja Rohwer, Reduction of Employment Protection in Europe: A Comparative Fuzzy-Set Analysis, October 2009

2829 Rainald Borck and Martin Wimbersky, Political Economics of Higher Education Finance, October 2009

2830 Torfinn Harding and Frederick van der Ploeg, Is Norway's Bird-in-Hand Stabilization Fund Prudent Enough? Fiscal Reactions to Hydrocarbon Windfalls and Graying Populations, October 2009

2831 Klaus Wälde, Production Technologies in Stochastic Continuous Time Models, October 2009

2832 Biswa Bhattacharyay, Dennis Dlugosch, Benedikt Kolb, Kajal Lahiri, Irshat Mukhametov and Gernot Nerb, Early Warning System for Economic and Financial Risks in Kazakhstan, October 2009

2833 Jean-Claude Trichet, The ECB’s Enhanced Credit Support, October 2009

2834 Hans Gersbach, Campaigns, Political Mobility, and Communication, October 2009

2835 Ansgar Belke, Gunther Schnabl and Holger Zemanek, Real Convergence, Capital Flows, and Competitiveness in Central and Eastern Europe, October 2009

2836 Bruno S. Frey, Simon Luechinger and Alois Stutzer, The Life Satisfaction Approach to Environmental Valuation, October 2009

2837 Christoph Böhringer and Knut Einar Rosendahl, Green Serves the Dirtiest: On the Interaction between Black and Green Quotas, October 2009

2838 Katarina Keller, Panu Poutvaara and Andreas Wagener, Does Military Draft Discourage Enrollment in Higher Education? Evidence from OECD Countries, October 2009

2839 Giovanni Cespa and Xavier Vives, Dynamic Trading and Asset Prices: Keynes vs. Hayek, October 2009 
2840 Jan Boone and Jan C. van Ours, Why is there a Spike in the Job Finding Rate at Benefit Exhaustion?, October 2009

2841 Andreas Knabe, Steffen Rätzel and Stephan L. Thomsen, Right-Wing Extremism and the Well-Being of Immigrants, October 2009

2842 Andrea Weber and Christine Zulehner, Competition and Gender Prejudice: Are Discriminatory Employers Doomed to Fail?, November 2009

2843 Hadi Salehi Esfahani, Kamiar Mohaddes and M. Hashem Pesaran, Oil Exports and the Iranian Economy, November 2009

2844 Ruediger Bachmann and Christian Bayer, Firm-Specific Productivity Risk over the Business Cycle: Facts and Aggregate Implications, November 2009

2845 Guglielmo Maria Caporale, Burcu Erdogan and Vladimir Kuzin, Testing for Convergence in Stock Markets: A Non-Linear Factor Approach, November 2009

2846 Michèle Belot and Jan Fidrmuc, Anthropometry of Love - Height and Gender Asymmetries in Interethnic Marriages, November 2009

2847 Volker Nitsch and Nikolaus Wolf, Tear Down this Wall: On the Persistence of Borders in Trade, November 2009

2848 Jan K. Brueckner and Stef Proost, Carve-Outs Under Airline Antitrust Immunity, November 2009

2849 Margarita Katsimi and Vassilis Sarantides, The Impact of Fiscal Policy on Profits, November 2009

2850 Scott Alan Carson, The Relationship between Stature and Insolation: Evidence from Soldiers and Prisoners, November 2009

2851 Horst Raff and Joachim Wagner, Intra-Industry Adjustment to Import Competition: Theory and Application to the German Clothing Industry, November 2009

2852 Erkki Koskela, Impacts of Labor Taxation with Perfectly and Imperfectly Competitive Labor Markets under Flexible Outsourcing, November 2009

2853 Cletus C. Coughlin and Dennis Novy, Is the International Border Effect Larger than the Domestic Border Effect? Evidence from U.S. Trade, November 2009

2854 Johannes Becker and Clemens Fuest, Source versus Residence Based Taxation with International Mergers and Acquisitions, November 2009 